\title{
Reversible Inhibition of Urea Exchange in Rat Hepatocytes
}

\author{
Richard M. Effros, Elizabeth Jacobs, Allen Hacker, Kutlan Ozker, and Connie Murphy \\ Division of Pulmonary and Critical Care, Department of Medicine, Medical College of Wisconsin, Milwaukee, Wisconsin 53226
}

\begin{abstract}
Urea exchange is enhanced in renal collecting duct cells and erythrocytes by transporters which can be inhibited by phloretin and urea analogs such as thiourea. In this study, evidence for a comparable transporter was found in rat livers perfused with solutions which contained no red cells and in suspensions of hepatocytes. Bolus injections containing ${ }^{125} \mathrm{I}$-albumin (intravascular indicator ), ${ }^{99 \mathrm{~m}} \mathrm{Tc}-\mathrm{DTPA}$ (extracellular indicator ), ${ }^{3} \mathrm{HOH}$ (water indicator), and $\left[{ }^{14} \mathrm{C}\right]$ urea were administered into the portal vein and fluid was collected from the hepatic vein. Under control conditions, $\left[{ }^{14} \mathrm{C}\right]$ urea and ${ }^{3} \mathrm{HOH}$ emerged from the hepatic vein at nearly the same rate. However when the perfusate contained $2.5 \mathrm{mM}$ phloretin (equivalent to $0.058 \mathrm{mM}$ phloretin not bound to albumin), the amount of $\left[{ }^{14} \mathrm{C}\right]$ urea which had been recovered in the hepatic venous outflow by the time of peak ${ }^{125} \mathrm{I}$-albumin concentrations exceeded ${ }^{3} \mathrm{HOH}$ recovery by a factor of $2.31 \pm 0.23(n=7)$. When the perfusate contained 200 $\mathrm{mM}$ thiourea, the comparable recovery of $\left[{ }^{14} \mathrm{C}\right]$ urea from the hepatic veins exceeded that of ${ }^{3} \mathrm{HOH}$ by a factor of $3.48 \pm 0.44$ $(n=7)$. These effects were at least partially reversible and suggested inhibition of urea transporters in hepatocytes. This conclusion was supported by studies of unloading of $\left[{ }^{14} \mathrm{C}\right]$ urea from hepatocytes which were exposed to unlabeled solutions: in the presence of phloretin, the amount of $\left[{ }^{14} \mathrm{C}\right]$ urea remaining within hepatocytes at $4 \mathrm{~s}$ was approximately twice that remaining in hepatocytes which had not been exposed to phloretin. Rapid transport of urea out of hepatocytes may increase urea synthesis and minimize cellular swelling due to urea accumulation. (J. Clin. Invest. 1993. 91:2822-2828.) Key words: urea • liver $\bullet$ transport $\bullet$ phloretin $\bullet$ thiourea
\end{abstract}

\section{Introduction}

Urea transporters have been described in a limited number of mammalian cells, notably red cells and a single type of renal cell located at the tip of the collecting ducts (1-5). These transporters accelerate diffusion across cell membranes by a factor of more than 100 and are inhibited by phloretin and high concentrations of urea or its analogs (e.g., thiourea) $(1,3,6)$. It has been suggested that enhanced transport of urea in red cells

An abstract presenting preliminary studies has recently been published: 1992. FASEB (Fed. Am. Soc. Exp. Biol.) J. 6:A2073.

Address correspondence and reprint requests to Dr. Richard $\mathbf{M}$. Effros, Division of Pulmonary and Critical Care, Department of Medicine, Medical College of Wisconsin, 9200 West Wisconsin Avenue, Milwaukee, WI 53226.

Received for publication 11 June 1992 and in revised form 10 December 1992.

J. Clin. Invest.

(C) The American Society for Clinical Investigation, Inc.

$0021-9738 / 93 / 06 / 2822 / 07 \$ 2.00$

Volume 91, June 1993, 2822-2828 serves to decrease the osmotic dehydration that would otherwise occur as they traverse the renal medulla (3). Location of the transporters in collecting duct cells permits return of urea to the medulla, keeping medullary stores of urea high and minimizing osmotic losses of water which would otherwise be obligated be excretion of high concentrations of urea $(4,5)$.

After injections into the portal vein, the rate of exchange of $\left[{ }^{14} \mathrm{C}\right.$ ] urea with the liver is very rapid and quite similar to that of ${ }^{3} \mathrm{H}_{2} \mathrm{O}(7,8)$. In contrast, exchange of $\left[{ }^{14} \mathrm{C}\right]$ urea with the lung parenchyma $(9,10)$, left ventricle $(11)$, and rete mirabile (12) is much more limited than that of ${ }^{3} \mathrm{HOH}$ during a single transit through these organs. Although hepatic production of urea represents the principal manner in which proteins are catabolized, it is not known whether urea transporters mediate exchange of urea between hepatocytes and plasma. In this study, we have obtained evidence for urea transporters in perfused rat livers and isolated liver cells. Indicator dilution methods were used to study $\left[{ }^{14} \mathrm{C}\right]$ urea exchange in perfused livers and a rapid filtration procedure was used to monitor $\left[{ }^{14} \mathrm{C}\right.$ ] urea unloading from isolated liver cells.

\section{Methods}

\section{Perfused liver preparation}

Experimental procedures. 18 Sprague-Dawley rats (average weight $401 \pm 51 \mathrm{~g}, \mathrm{SD}$ ) were anesthetized with an injection of $0.65 \mathrm{ml}$ i.m. of a $64.8 \mathrm{mg} / \mathrm{ml}$ solution of pentobarbital. Catheters were placed in the portal vein and inferior vena cava and positioned close to the hepatic veins. The portal vein catheter was secured with a suture, and sutures were placed around the inferior vena cava above and below the site at which the hepatic veins enter the vena cava. The livers were perfused by a syringe pump at $37^{\circ} \mathrm{C}$ with a control solution containing $25 \mathrm{mM}$ $\mathrm{NaHCO}_{3}, 110 \mathrm{mM} \mathrm{NaCl}, 4 \mathrm{mM} \mathrm{KCl}, 2.5 \mathrm{mM} \mathrm{CaCl}_{2} 0.8 \mathrm{mM} \mathrm{MgSO}_{4}$, $150 \mathrm{mg} / \mathrm{dl}$ glucose, $10 \mathrm{mg} / \mathrm{dl}$ urea and $5 \mathrm{~g} / \mathrm{dl}$ bovine serum albumin (Cohn fraction V, 98-99\% pure; Sigma Chemical Co., St. Louis, MO) adjusted to $\mathrm{pH} 7.4$ when exposed to $5 \% \mathrm{CO}_{2}$ at $37^{\circ} \mathrm{C}$. In seven rats, the livers were perfused with the control solution and with a solution which contained $2.5 \mathrm{mM}$ phloretin. In an additional seven rats, the livers were perfused with a control solution and a solution which contained 200 $\mathrm{mM}$ thiourea. The sequence of control and experimental solutions was randomized. The thiourea solution was kept isosmotic by reducing the amount of $\mathrm{NaCl}$ to keep osmolality constant as judged by a vapor pressure osmometer (Wescor, Logan, UT). The effect of replacing the same amount of $\mathrm{NaCl}$ with $200 \mathrm{mM}$ mannitol was studied in four more experiments. The rate of perfusion in the thiourea experiments averaged $13.3 \mathrm{ml} / \mathrm{min}$. Somewhat higher rates of perfusion were used in the phloretin and mannitol experiments (see Tables I-II).

Indicators. A volume of $0.135 \mathrm{ml}$ of a radioactive solution was injected into the portal vein with a chromatography injection valve (Type 50; Rheodyne, Inc., Cotati, CA). The injection solution contained $0.15 \mu \mathrm{Ci}{ }^{125} \mathrm{I}$-albumin (human serum albumin labeled with ${ }^{125} \mathrm{I}$; Mallinckrodt Medical, Inc., St. Louis, MO), $1.0 \mu \mathrm{Ci}$ diethylenetriaminepentaacetic acid $\left({ }^{99 \mathrm{~m}} \text { Tc-DTPA }\right)^{1}$ (CIS-US Inc., Bridge-

1. Abbreviations used in this paper: ${ }^{99 \mathrm{~m}} \mathrm{Tc}$-DTPA, diethylenetriaminepentaacetic acid. 
Table I. Experimental Solutions Used for Isolation of Hepatocytes*

\begin{tabular}{|c|c|c|c|c|c|}
\hline Constituent & Source & $\mathrm{Ca}^{++}$free buffer & Collagenase buffer & Washing buffer & Suspension buffer \\
\hline $\mathrm{NaCl} \mathrm{mg}$ & $\mathrm{F}$ & 8300 & 3900 & 8300 & 4000 \\
\hline $\mathrm{KCl} \mathrm{mg}$ & $\mathbf{M}$ & 500 & 500 & 500 & 400 \\
\hline $\mathrm{CaCl}_{2} \cdot 2 \mathrm{H}_{2} \mathrm{O} \mathrm{mg}$ & $\mathbf{F}$ & & 700 & 180 & 180 \\
\hline $\mathrm{MgCl}_{2} \cdot 6 \mathrm{H}_{2} \mathrm{O} \mathrm{mg}$ & $\mathrm{F}$ & & & & 130 \\
\hline $\mathrm{KH}_{2} \mathrm{PO}_{4} \mathrm{mg}$ & $\mathrm{F}$ & & & & 150 \\
\hline $\mathrm{Na}_{2} \mathrm{SO}_{4} \mathrm{mg}$ & $\mathbf{M}$ & & & & 100 \\
\hline HEPES mg & $S$ & 2400 & 24000 & 2400 & 7200 \\
\hline TES $\mathrm{mg}$ & $\mathrm{K}$ & & & & 6900 \\
\hline Tricine $\mathrm{mg}$ & K & & & & 6500 \\
\hline $1 \mathrm{M} \mathrm{NaOH} \mathrm{ml} / \mathrm{l}$ & $\mathbf{M}$ & 5.5 & 66 & 5.5 & 52.5 \\
\hline Collagenase mg & S & & 500 & & \\
\hline $\mathrm{pH}$ & & 7.4 & 7.6 & 7.4 & 7.6 \\
\hline
\end{tabular}

* Adapted from Seglen (16). Quantities of solutes present in each liter of solution are tabulated. HEPES = (N-[2-hydroxyethyl]piperazine-N'-[2ethanesulfonic acid]), TES, $N$-[2-hydroxy-1,1-bis-(hydroxy-methyl)ethyl)ethyl]-taurine; Tricine, $N$-[tris(hydroxymethyl)methyl]glycine, F, Fisher Scientific, Itasca, IL; K, Eastman Kodak Co, Rochester, NY. M, Mallinckrodt, Inc.; S, Sigma Chemical Co., St. Louis, MO.

port, CT), $1.6 \mu \mathrm{Ci}{ }^{3} \mathrm{H}_{2} \mathrm{O}$, and $1.6 \mu \mathrm{Ci}\left[{ }^{14} \mathrm{C}\right]$ urea in an isotonic saline solution. Less than $1 \%$ of the ${ }^{125} \mathrm{I}$-albumin was filtered through an ultrafilter with a cut-off of 30,000 D (YM30 membrane; Amicon, Beverly, MA) indicating that most of the ${ }^{125} \mathrm{I}$ was bound to the albumin. Samples of hepatic venous outflow were collected at 2-s intervals with a mechanical collection rack. More than $99 \%$ of the $\left[{ }^{14} \mathrm{C}\right]$ urea in the injection solution and in fluid collected from the liver was released by urease, indicating that the virtually all of the ${ }^{14} \mathrm{C}$ label was in the form of $\left[{ }^{14} \mathrm{C}\right]$ urea and $\left[{ }^{14} \mathrm{C}\right]$ urea was not metabolized by the liver.

Analysis. Samples were analyzed in automated gamma and beta counters, and the counts were corrected for background, cross-over, and decay (for ${ }^{99 \mathrm{~m}} \mathrm{Tc}$-DTPA). Counts attributable to each indicator were divided by the quantities injected to yield fractional concentrations, $[X]$, which were plotted against time (Figs. 1-3). The areas $(A)$ under fractional concentration curves of each of the indicators up to the point at which ${ }^{125}$ I-albumin concentrations had become maximal were calculated with the equation:

$A(X)=\sum_{a}^{b}[X] \Delta t$ where $[X]$ is the fractional concentration of the indicator $\left(\mathrm{ml}^{-1}\right), \Delta t$ is the sampling interval (in seconds), $a$ is the time at which fractional concentrations of ${ }^{125} \mathrm{I}$-albumin have reached $5 \%$ of the peak values, and $b$ is the time at which fractional concentrations of ${ }^{125} \mathrm{I}$-albumin have reached peak values. The ratio $A\left({ }^{99 m}\right.$ Tc-DTPA $) / A\left({ }^{125} \mathrm{I}\right.$-albumin $)$ was calculated and is equivalent to the transmission, $T$, of ${ }^{99 \mathrm{~m}} \mathrm{Tc}$-DTPA (13). In organs with continuous endothelial beds, $T$ can provide information concerning capillary permeability, but open fenestra in the liver sinusoids permit rapid equilibration of labeled albumin with the interstitium, as demonstrated by Goresky (14). Values of $A\left({ }^{99 \mathrm{~m}} \mathrm{Tc}\right.$ DTPA )/ $A\left({ }^{125} \mathrm{I}\right.$-albumin $)$ were calculated to determine if exposure to phloretin, thiourea, or mannitol altered either the permeability of the barriers separating the perfusate from the interstitium or the extracellular volume of distribution of ${ }^{99 \mathrm{~m}} \mathrm{Tc}$-DTPA. Because the molecular weight of ${ }^{99 m}$ Tc-DTPA (492 D) is much closer to that of $\left[{ }^{14} \mathrm{C}\right]$ urea $(80$ D) than that of ${ }^{125} \mathrm{I}$-albumin $(64,000),{ }^{99 \mathrm{~m}} \mathrm{Tc}$-DTPA provides a more suitable extracellular indicator for assessing intracellular diffusion of $\left[{ }^{14} \mathrm{C}\right]$ urea and ${ }^{3} \mathrm{HOH}$, and ratios of $A\left(\left[{ }^{14} \mathrm{C}\right]\right.$ urea $)$ and $A\left({ }^{3} \mathrm{HOH}\right)$ to $A\left({ }^{99 \mathrm{~m}}\right.$ Tc-DTPA) are tabulated in Table II (peaks of ${ }^{125} \mathrm{I}$-albumin and ${ }^{99 m}$ Tc-DTPA were very similar and the former were retained for consis-

Table II. Indicator Dilution Data*

\begin{tabular}{lcccc}
\hline & Control $(n=13)$ & Phloretin $(n=7)$ & Thiourea $(n=7)$ & Mannitol $(n=4)$ \\
\hline$F$ & $15.5 \pm 0.5$ & $18.1 \pm 1.1$ & $13.4 \pm 1.1$ & $15.4 \pm 0.2$ \\
$t_{\text {albumin }}$ & $42.7 \pm 2.50$ & $42.5 \pm 2.7$ & $33.9 \pm 3.6^{\ddagger}$ & $45.8 \pm 3.2$ \\
$\mathrm{~A}(\mathrm{DTPA}) / \mathrm{A}($ albumin $)$ & $0.827 \pm 0.022$ & $0.831 \pm 0.032$ & $0.884 \pm 0.028$ & $0.843 \pm 0.026$ \\
$A($ water $) / A(\mathrm{DTPA})$ & $0.381 \pm 0.018$ & $0.353 \pm 0.025$ & $0.140 \pm 0.053^{\S}$ & $0.185 \pm 0.038^{\S}$ \\
$A$ (urea) $/ A$ (DTPA) & $0.347 \pm 0.007$ & $0.792 \pm 0.054^{\S}$ & $0.370 \pm 0.059$ & $0.175 \pm 0.035^{\ddagger}$ \\
$A$ (urea) $/ A$ (water) & $0.936 \pm 0.045$ & $2.315 \pm 0.225^{\S}$ & $3.481 \pm 0.594^{\S}$ & $0.946 \pm 0.068$ \\
$R$ (DTPA) & $0.984 \pm 0.012$ & $0.982 \pm 0.014$ & $0.989 \pm 0.019$ & $1.001 \pm 0.023$ \\
$R$ (water) & $0.974 \pm 0.036$ & $0.953 \pm 0.026$ & $0.826 \pm 0.030$ & $1.087 \pm 0.082$ \\
$R$ (urea) & $1.043 \pm 0.118$ & $0.842 \pm 0.014$ & $0.747 \pm 0.029$ & $1.036 \pm 0.218$ \\
$\Delta V_{\text {DTPA }}$ & $0.257 \pm 0.090$ & $0.441 \pm 0.147$ & $0.443 \pm 0.091$ & $0.249 \pm 0.139$ \\
$\Delta V_{\text {water }}$ & $4.20 \pm 0.87$ & $3.39 \pm 0.28$ & $7.10 \pm 2.58$ & $9.28 \pm 1.73^{*}$ \\
Liver weight & - & $15.1 \pm 0.3$ & $23.4 \pm 2.14$ & $23.3 \pm 1.86$
\end{tabular}

\footnotetext{
* Means and standard errors. Control values were obtained from those experiments in which the control solution was used before the phloretin, thiourea or mannitol solutions. Significance of differences in mean values of experimental from control data were determined by Dunnet's test following ANOVA. As indicated in the text, insufficient downslope data was collected in 1 phloretin and 2 thiourea experiments to make it possible to calculate $R$ (water), $R$ (urea) or $\Delta V_{\text {water }}$ and these data were not included in the calculations. ${ }^{\ddagger} P<0.05,{ }^{\S} P<0.01$.
} 
tency in calculating values of $A$ for each of the indicators). Low values of these ratios indicate greater intracellular distribution. Ratios were also calculated for $A\left(\left[{ }^{14} \mathrm{C}\right]\right.$ urea $) / A\left({ }^{3} \mathrm{HOH}\right)$, as an index of the relative extent to which these two indicators had equilibrated with the intracellular volume by the time that ${ }^{125} \mathrm{I}$-albumin concentrations had become maximal. $A\left({ }^{125} \mathrm{I}\right.$-albumin $)$ is designated as $A$ (albumin $), A\left(\left[{ }^{14} \mathrm{C}\right]\right.$ urea $)$ as $A$ (urea), and $A\left({ }^{3} \mathrm{HOH}\right)$ as $A$ (water) in the remainder of the text for simplicity.

For calculations of flow $(F)$, total recovery $(R)$, and mean transit times $(\bar{t})$, the outflow curves of each of the indicators were extrapolated to infinity by plotting fractional concentrations on a logarithmic ordinate against time on a linear abscissa and using the least-squares best fit of the last five sample concentrations to extend the curve beyond the last measured sample. The recoveries $(R)$ of the diffusible indicators $\left({ }^{99 \mathrm{~m}} \mathrm{Tc}-\mathrm{DTPA},{ }^{3} \mathrm{HOH}\right.$, and $\left[{ }^{14} \mathrm{C}\right]$ urea $)$ were calculated by dividing the areas under the extrapolated outflow curves of these indicators by the area under the extrapolated ${ }^{125} \mathrm{I}$-albumin curve as described previously (15). The rate of perfusion, $F$, was calculated from the reciprocal of the area under the extrapolated ${ }^{125} \mathrm{I}$-albumin curve and the mean transit times, $\bar{t}$, were calculated in the conventional fashion from the equation:

$\bar{t}=\frac{\int_{\alpha}^{\infty}[X] t \mathrm{~d} t}{\int_{\alpha}^{\infty}[X] \mathrm{d} t}$

where the integrals were estimated from the extrapolated indicator dilution curves (15). Volumes of indicator distribution were calculated from the products of flow and mean transit times, and were corrected for the catheter volume. The volume of distribution of ${ }^{125} \mathrm{I}$-albumin was subtracted from that of the diffusible indicators to yield extravascular volumes $(\Delta V)$. Estimates of recoveries and mean transit times of ${ }^{3} \mathrm{HOH}$ and $\left[{ }^{14} \mathrm{C}\right]$ urea could not be made in one of the seven phloretin and two of the seven thiourea experiments because insufficient data were collected at late times to permit accurate estimates of the downslopes of these curves. Because of the likelihood that the downslopes of the urea curves were not monoexponential, particularly after inhibition with phloretin and urea, no attempt was made to calculate $\Delta V$ of $\left[{ }^{14} \mathrm{C}\right]$ urea. A more comprehensive analysis is possible with the mathematical model outlined by Goresky et al. (7), but this was not necessary to demonstrate the presence of urea transporters in the present study.

Binding of phloretin to albumin was quantified by filtering $2.5 \mathrm{mM}$ phloretin in the perfusate solution, which contained $5 \mathrm{~g} / \mathrm{dl}$ albumin through an Amicon YM30 membrane with a 30,000-D molecular mass filter (see above). Phloretin concentrations were determined spectrophotometrically at $320 \mathrm{~nm}$ in protein-free solutions: the optical density of the filtrate was compared to that present in a protein-free solution, which contained the same amount of phloretin as the filtrand and which was diluted prior to spectrophotometry.

Means of the indicator dilution data (Table II) were compared by first calculating a one-way, completely randomized ANOVA for each parameter and then using a Dunnet's test to determine if values in the phloretin, thiourea, and mannitol experiments differed from control values. Weights were not obtained after livers had been perfused with only the control solution but the means of the thiourea and mannitol weights were compared with those of phloretin by the same statistical approach.

\section{Isolated hepatocytes}

Preparation of cells. Hepatocytes were isolated and purified from five rats in the manner similar to that described in great detail by Seglen (16). The portal vein was catheterized as indicated above but no catheter was placed in the inferior vena cava. The liver was perfused at 30 $\mathrm{ml} / \mathrm{min}$ with $300 \mathrm{ml}$ of an oxygenated $\mathrm{Ca}^{++}$free perfusion buffer (see Table I) at $37^{\circ} \mathrm{C}$. During this perfusion the liver was excised and the flow rate was increased to $50 \mathrm{ml} / \mathrm{min}$ until the solution was depleted. The liver was then placed on a nylon filter which rested on a perforated plastic dish mounted on a beaker. A collagenase buffer solution was infused at $50 \mathrm{ml} / \mathrm{min}$ into the liver and fluid collected from the beaker was recirculated for $10 \mathrm{~min}$ through the organ. The liver was then placed into a petri dish containing $75 \mathrm{ml}$ of a suspension buffer. The liver was raked with a stainless steel comb to release the parenchyma and the cells which were released were filtered through a $250 \mu \mathrm{m}$ nylon mesh (all nylon meshes were obtained from Tetko, Inc., Briarcliff Manor, NY). The cell suspension was placed in a large petri dish which was shaken in a $37^{\circ}$ water bath for $30 \mathrm{~min}$, and then placed in ice for 5 min, after which they were passed through a $250-\mu \mathrm{m}$ mesh and a $100-$ $\mu \mathrm{m}$ mesh which were layered on top of one another. The filtrate was then spun at $200 \mathrm{rpm}(5 \mathrm{~g})$ for $5 \mathrm{~min}$ and the supernatant was removed and discarded. The cells were washed and centrifuged three times with $35 \mathrm{ml}$ of a washing buffer. The resulting pellet was resuspended in 30 $\mathrm{ml}$ of suspension buffer and passed through a $61 \mu \mathrm{m}$ nylon mesh for the final cell suspension. This procedure yielded what appeared on microscopy to be $>97 \%$ hepatocytes, as described by Seglen (16). Furthermore, $>99 \%$ of the cells excluded trypan blue prior to equilibration with $\left[{ }^{14} \mathrm{C}\right]$ urea and $>97 \%$ excluded trypan blue after equilibration, suggesting that most of the cells were viable during this period.

Equilibration and unloading with $\left[{ }^{14} \mathrm{C}\right]$ urea. Two $500-\mu \mathrm{l}$ aliquots of liver cell suspensions were used to compare unloading of $\left[{ }^{14} \mathrm{C}\right]$ urea from cells that had been exposed to either phloretin or the suspension buffer without phloretin. $200 \mu \mathrm{l}$ of a solution containing $1.3 \mu \mathrm{Ci}$ of ${ }^{125}$ I-albumin (human serum) and $9 \mu \mathrm{Ci}\left[{ }^{14} \mathrm{C}\right]$ urea were added to the aliquots and incubated at $25^{\circ} \mathrm{C}$ for $30 \mathrm{~min}$ in a shaking water bath. ${ }^{125} \mathrm{I}$-albumin was included in this solution to permit calculation of the fractional cell volume of the hepatocytes in the pellet as described below. $400 \mu \mathrm{l}$ of either the suspension buffer containing $10 \mathrm{mg} / \mathrm{dl}$ urea and $0.1 \mathrm{~g} / \mathrm{dl}$ albumin (bovine serum) or $100 \mu \mathrm{M}$ phloretin in this buffer was added to the suspension for an additional $10 \mathrm{~min}$. (It is difficult to dissolve more phloretin in the buffer without albumin, and the resulting solution had a concentration of $37 \mu \mathrm{M}$ ). Both the control and the phloretin suspensions were spun at $200 \mathrm{rpm}$ for $5 \mathrm{~min}$ and $5 \mu \mathrm{l}$ samples of the supernatant and pellet were obtained for measurements of radioactivity and subsequent calculation of cell volume (see below). A $1 \mu \mathrm{l}$ sample of the pellet were placed on a $0.45 \mu \mathrm{m}$ Millipore ${ }^{\mathrm{R}}$ Multiscreen filter simultaneously with $250 \mu \mathrm{l}$ of the suspension buffer containing $0.8 \mu \mathrm{Ci} / \mathrm{ml}$ of $\left[{ }^{3} \mathrm{H}\right]$ sucrose and $10 \mathrm{mg} / \mathrm{dl}$ unlabeled sucrose, 10 $\mathrm{mg} / \mathrm{dl}$ urea, and $0.1 \mathrm{~g} / \mathrm{dl}$ albumin. (Low concentrations of albumin, urea, and sucrose were utilized to prevent non-specific binding to the containers.) After 4, 30, and $60 \mathrm{~s}$, suction was applied to the filters, thereby separating the cells from the supernatant. The filters were dried with an infrared lamp and the filters were punched out by a Millipore cell harvester and placed in $2 \mathrm{ml}$ of Optiphase ${ }^{\mathrm{R}}$ II scintillant. The filters and $100-\mu 1$ samples of the filtrates were added to $2 \mathrm{ml}$ of Optiphase ${ }^{\mathrm{R}}$ Hisafe 3 scintillant (Wallac/LKB Inc., Gaithersburg, MD) and counted as indicated above.

Calculations. ${ }^{125} \mathrm{I}$-albumin was included in the incubation solution with $\left[{ }^{14} \mathrm{C}\right]$ urea to permit calculation of the fractional cell volume of the pellet, which was subsequently placed on the filters. It was assumed that ${ }^{125}$ I-albumin remained extracellular during the equilibration period. After correction of counts for cross-over and background, the fractional cell volume $f$ of hepatocytes in the pellet that was used for unloading was calculated from the ${ }^{125} \mathrm{I}$-albumin concentration in the pellet $[A]_{p}$ and that in the suspension $[A]_{s}$ with the equation:

$f=1-[A]_{p} /[A]_{s}$

Once the value of $f$ was known, it was possible to determine the amount of intracellular $\left[{ }^{14} \mathrm{C}\right]$ urea which was initially placed on the membrane in the following fashion: The concentration $[U]_{c, 0}$ of $\left[{ }^{14} \mathrm{C}\right]-$ urea present in the hepatocytes which were placed on the membrane at the end of equilibration was calculated from the concentration in the pellet $[U]_{p}$, the concentration in the supernatant $[U]_{s}$, and $f$ with the equation:

$[U]_{c, 0}=\frac{[U]_{p}-[U]_{s}(1-f)}{f}$ 


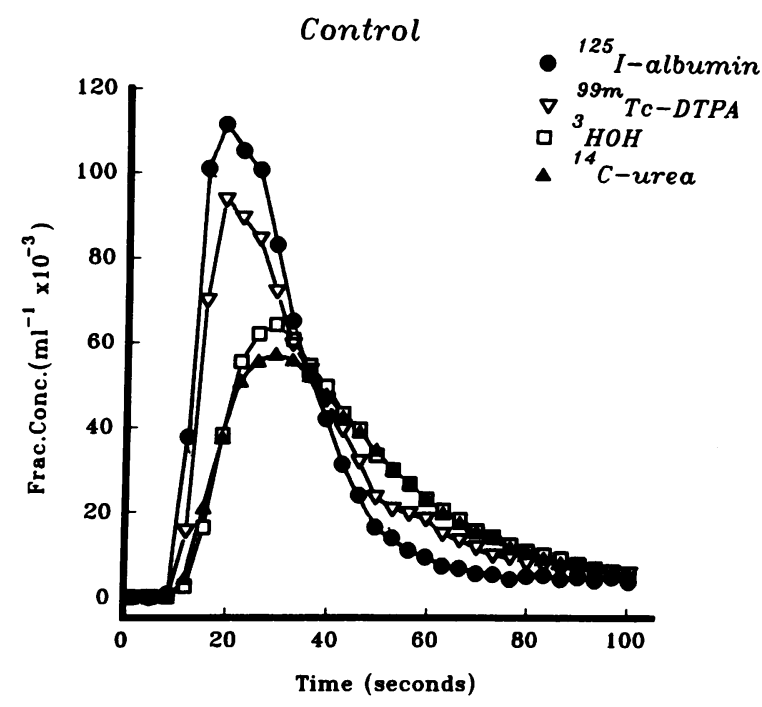

and the quantity of urea $U_{c, m, 0}$ within the hepatocytes originally placed on the filter was calculated from the equation

$U_{c, m, 0}=f V[U]_{c, 0}$

where $V$ is the volume of the pellet injected onto the filter $(1 \mu l)$.

$\left[{ }^{3} \mathrm{H}\right]$ Sucrose was incorporated in the diluent so that the volume of extracellular fluid and the amount of extracellular $\left[{ }^{14} \mathrm{C}\right]$ urea remaining on the membrane after filtration could be calculated. The amount of intracellular urea $U_{c, m, t}$ on the membrane at time $t$, when suction was applied to remove the diluent from the membrane, was calculated from the equation:

$U_{c, m, t}=U_{m, t}-[U]_{f, t} \frac{S_{m, t}}{[\mathrm{~S}]_{f, t}}$

where the volume of extracellular fluid remaining on the membrane after filtration is calculated from the ratio of the $\left[{ }^{3} \mathrm{H}\right]$ sucrose on the membrane $S_{m, t}$ to the concentration $[S]_{f, t}$ of sucrose in the filtrate, $[U]_{f, t}$ is the concentration of urea in the filtrate at the time of filtration and the second term on the right side of Eq. 6 represents the amount of $\left[{ }^{14} \mathrm{C}\right.$ ] urea in the extracellular fluid remaining on the membrane. Values were then calculated for the fraction, $U_{c, m, t} / U_{c, m, 0}$, of intracellular $\left[{ }^{14} \mathrm{C}\right.$ ] urea remaining on the membrane at 4,30 , and $60 \mathrm{~s}$. The amounts
Phloretin

Figure 1. Phloretin studies. Prior to exposure to phloretin (control run), the outflow patterns of $\left[{ }^{14} \mathrm{C}\right]$ urea and ${ }^{3} \mathrm{HOH}$ are similar. Following 2 min of perfusion with 2.5 $\mathrm{mM}$ phloretin $(0.065 \mathrm{mM}$ unbound phloretin), $\left[{ }^{14} \mathrm{C}\right]-$ urea emerged from the hepatic veins in advance of ${ }^{3} \mathrm{HOH}$. of $\left[{ }^{14} \mathrm{C}\right]$ urea remaining in hepatocytes in the presence and absence of phloretin was calculated with a two-way analysis of variance with repeated measures (for each time interval).

\section{Results}

Perfused liver preparation. As indicated in Figs. 1-3, the outflow patterns of $\left[{ }^{14} \mathrm{C}\right]$ urea were relatively close to those of ${ }^{3} \mathrm{HOH}$ in the control experiments. After 2 min of perfusion with phloretin (Fig. 1) the outflow pattern of $\left[{ }^{14} \mathrm{C}\right]$ urea was shifted toward that of ${ }^{99 \mathrm{~m}} \mathrm{Tc}$-DTPA, an indicator which remains extracellular. This was reflected by significant increases in $A$ (urea) $/ A$ (DTPA) and $A$ (urea) $/ A$ (water) (see Fig. 1 and Table II). Phloretin did not have significant effects on the outflow patterns of the indicators other than that of $\left[{ }^{14} \mathrm{C}\right]$ urea. These observations were consistent with the conclusion that phloretin inhibited urea uptake by hepatocytes. Only $2.3 \%$ of the phloretin traversed an ultrafilter with a cutoff of 30,000 D (see Methods), suggesting that the remainder was bound to albumin and that the concentration of free phloretin in the perfusate was $0.058 \mathrm{mM}$.

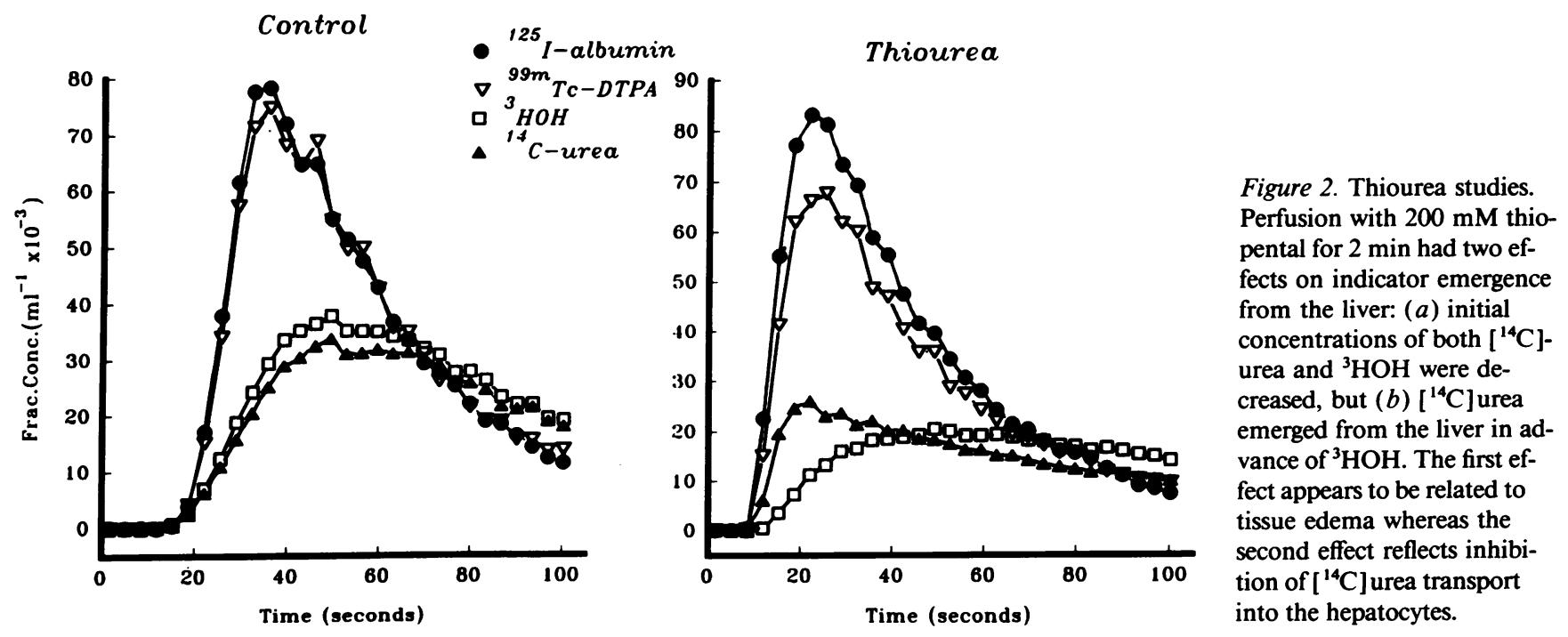



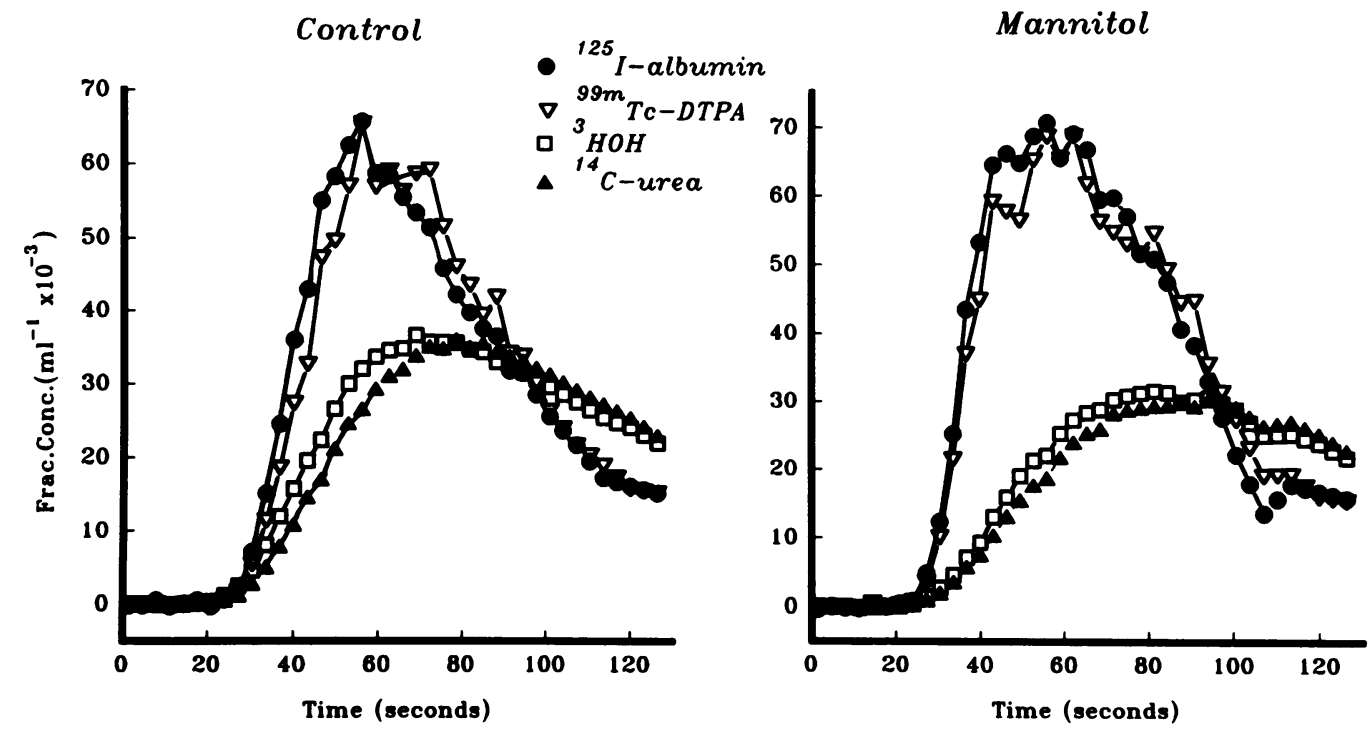

Figure 3. Mannitol studies. Perfusion with $200 \mathrm{mM}$ mannitol for 2 min decreased initial concentrations of both $\left[{ }^{14} \mathrm{C}\right]$ urea and ${ }^{3} \mathrm{HOH}$ relative to ${ }^{125} \mathrm{I}$-albumin and ${ }^{99 \mathrm{~m}} \mathrm{Tc}$ DTPA but did not shift the $\left[{ }^{14} \mathrm{C}\right]$ urea curve to earlier times than ${ }^{3} \mathrm{HOH}$. Although livers perfused with this solution became edematous, mannitol did not inhibit urea exchange with hepatocytes.

Perfusion of the liver with the solution containing $200 \mathrm{mM}$ thiourea for $2 \mathrm{~min}$ appeared to have two major effects on the outflow curves of the indicators (Fig. 2). In six of seven experiments, $A$ (water) $/ A$ (DTPA) was less after perfusion with thiourea than with the control solution $(P<0.01)$ and $\Delta V_{\text {water }}$ was increased in four of the five experiments in which enough late samples were collected to allow this calculation (this difference was not quite significant, see Table II). These observations were consistent with tissue swelling, a conclusion which was supported by the observation that the weight of the livers averaged $5.96 \pm 0.48 \%(\mathrm{SEM}, n=7)$ of bodyweight, whereas liver weight averaged only $3.84 \pm 0.12 \%(n=7)$ of bodyweight after the phloretin experiments $(P<0.01)$. Evidence for tissue swelling was also observed when $200 \mathrm{mM}$ mannitol rather than thiourea was placed in the perfusate solution in place of equiosmolal quantities of $\mathrm{NaCl}$ (Fig. 3): $A$ (water)/ $A$ (DTPA) fell significantly whereas $\Delta V_{\text {water }}$ increased significantly (Table II) and the liver weight was $5.05 \pm 0.32 \%$ of the total body weight, which was significantly more than that observed in the phloretin experiments $(P<0.05)$. Neither thiourea nor mannitol influenced $\Delta V_{\text {DTPA }}$ nor $A\left({ }^{99 \mathrm{~m}}\right.$ Tc-DTPA $) / A\left({ }^{125} \mathrm{I}\right.$-albumin $)$, suggesting that tissue swelling was related to cellular rather than interstitial edema.

In addition to inducing cellular edema, thiourea appeared to increase differences between the outflow patterns of $\left[{ }^{14} \mathrm{C}\right]-$ urea and ${ }^{3} \mathrm{HOH}$. Following infusions of $200 \mathrm{mM}$ thiourea, $\left[{ }^{14} \mathrm{C}\right.$ ] urea emerged from the hepatic veins in advance of ${ }^{3} \mathrm{HOH}: A$ (urea) $/ A$ (water) increased significantly (see Table II and Fig. 2). Although infusions of comparable concentrations of mannitol appeared to make the liver edematous ( see above), they did not cause $\left[{ }^{14} \mathrm{C}\right]$ urea to traverse the liver more slowly than ${ }^{3} \mathrm{HOH}$ ( Table II). These observations suggest that perfusion with thiourea inhibits $\left[{ }^{14} \mathrm{C}\right]$ urea exchange with hepatocytes whereas perfusion with mannitol does not have this effect. For reasons which were not clear, $\bar{t}_{\text {albumin }}$ in the thiourea studies was somewhat less than that in the other experiments, but it was not significantly different from the values observed in controls of the same experiments.

In three of the seven thiourea experiments and three of the seven phloretin experiments, the liver was perfused with the experimental solution before the control solution (Fig. 3). In each of these studies, the effects of thiourea and phloretin on urea movement into the tissues were decreased in the following control runs, suggesting that inhibition of urea transport was at least partly reversible (Fig. 4).

Isolated hepatocytes. As indicated in Fig. 5, the fraction of $\left[{ }^{14} \mathrm{C}\right]$ urea remaining within the hepatocytes at 4,30 , and $60 \mathrm{~s}$ after unloading was greater by a factor of about 2 when the hepatocytes had been exposed to phloretin ( $37 \mu \mathrm{M}$ phloretin for $10 \mathrm{~min}$ after loading with $\left[{ }^{14} \mathrm{C}\right]$ urea and $100 \mu \mathrm{M}$ phloretin
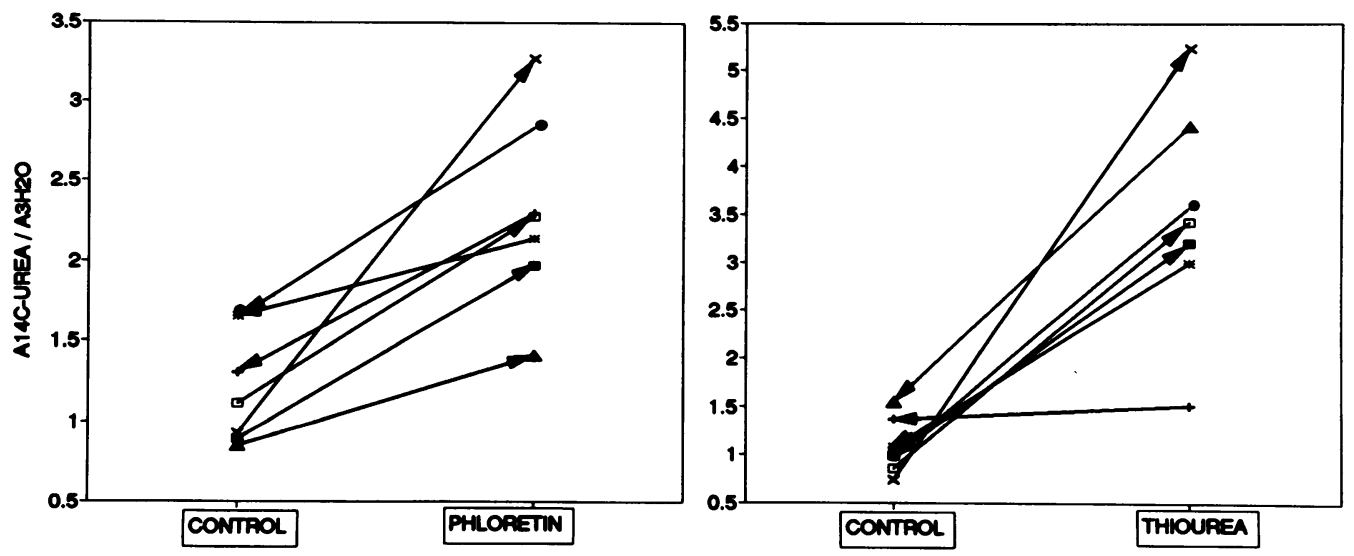

Figure 4. Effects of perfusion with phloretin and thiourea upon the ratio of the initial cumulative recovery of $\left[{ }^{14} \mathrm{C}\right]$ urea to that of ${ }^{3} \mathrm{HOH}$ [ $A\left(\left[{ }^{14} \mathrm{C}\right]\right.$ urea $\left.) / A\left({ }^{3} \mathrm{HOH}\right)\right]$. Increases in this ratio with exposure to thiourea and phloretin reflect inhibition of $\left[{ }^{14} \mathrm{C}\right]$ urea transport into the hepatocytes. This effect appeared to be reversible (the direction of the arrows indicates the sequence of the control and experimental runs). 


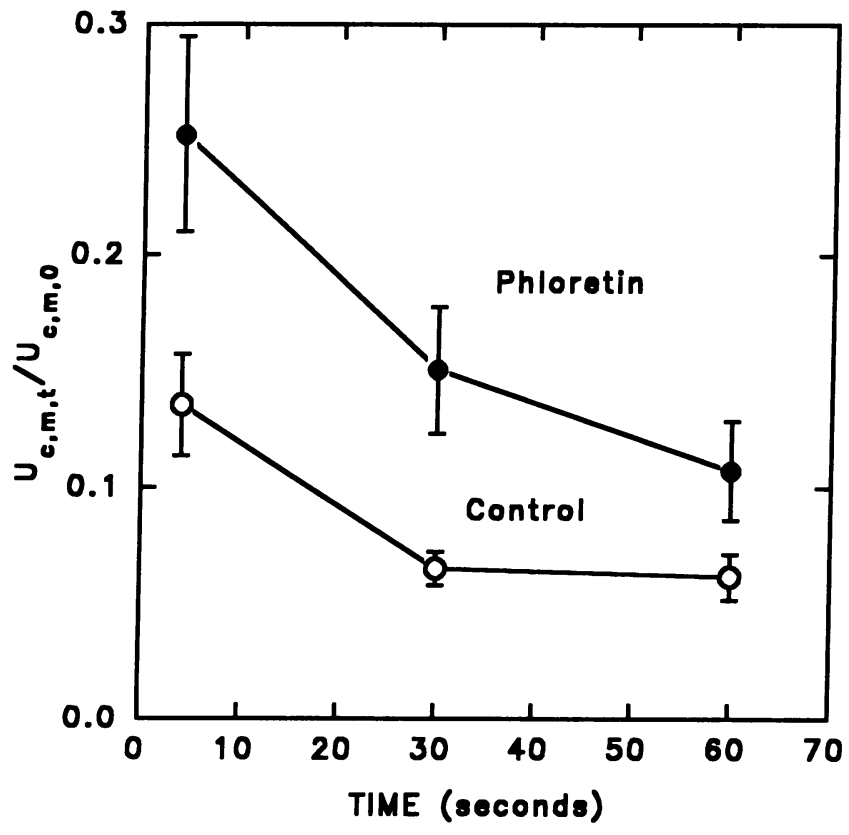

Figure 5. Unloading of $\left[{ }^{14} \mathrm{C}\right]$ urea from hepatocytes exposed to phloretin or control solutions. $U_{c, m, t} / U_{c, m, 0}$ indicates the fraction of intracellular $\left[{ }^{14} \mathrm{C}\right]$ urea remaining on the filters after various intervals of unloading. Initial losses of $\left[{ }^{14} \mathrm{C}\right]$ urea were rapid, but the amount remaining in the hepatocytes exposed to phloretin was greater than that in hepatocytes exposed to the control solution.

during unloading) than in control experiments $(P<0.025)$. Losses of $\left[{ }^{14} \mathrm{C}\right]$ urea from the hepatocytes were initially very rapid, suggesting diffusion of label out of a population of cells which were very permeable to $\left[{ }^{14} \mathrm{C}\right]$ urea, perhaps because of impact with the filter membranes. Slower rates of loss were observed thereafter $(P<0.01$ for decrease in hepatocyte concentrations between 4 and $60 \mathrm{~s}$ ).

\section{Discussion}

Detection of urea transporters in cell membranes currently depends upon inhibition with phloretin, and with urea or its analogs. It has been noted that low concentrations of phloretin slow transport of $\left[{ }^{14} \mathrm{C}\right]$ urea into the red cells, renal collecting duct cells, and amphibian bladders (17-19). Phloretin is a sulfhydryl binding agent that affects a variety of transporters on the cellular surfaces, such as those involved with glucose and chloride transport in red cells $(20,21)$. Its action is therefore nonspecific but the observation that it dramatically slows urea transport out of the hepatic vasculature and out of preloaded hepatocytes is consistent with an effect on transporter(s) responsible for urea exchange between the hepatic sinusoids and the surrounding hepatocytes.

Relatively high concentrations of urea are needed to inhibit transport of urea across the cell membranes of erythrocytes and inner medullary collecting duct cells. Apparent $K_{\mathrm{m}}$ values of between $30 \mathrm{mM}$ and greater than $800 \mathrm{mM}$ have been reported $(22,23)$. Urea derivatives such as thiourea can be used to inhibit urea transport in both red cells and inner medullary collecting duct cells $(2,18,22)$. Chou and Knepper have reported that $200 \mathrm{mM}$ thiourea inhibits urea transport by $75 \%$ in inner medullary collecting duct cells (22). The observation in these studies that $\left[{ }^{14} \mathrm{C}\right]$ urea emerges in advance of ${ }^{3} \mathrm{HOH}$ from the liver following infusions of $200 \mathrm{mM}$ of thiourea suggests a similar carrier in hepatocyte membranes. Unfortunately, high concentrations of both thiourea and mannitol resulted in what appeared to be swelling of hepatocytes and evidence has been obtained for diffusion of both thiourea (24) and mannitol (25) into hepatocytes. However, although mannitol delayed emergence of both $\left[{ }^{14} \mathrm{C}\right.$ ] urea and ${ }^{3} \mathrm{HOH}$ from the hepatic veins, it did not alter the relative rates at which these indicators appeared in the outflow: $A\left(\left[{ }^{14} \mathrm{C}\right]\right.$ urea $) / A\left({ }^{3} \mathrm{HOH}\right)$ remained unchanged. These observations indicate that though both thiourea and mannitol induced cellular edema, only thiourea had a significant effect on $\left[{ }^{14} \mathrm{C}\right]$ urea transport across cell membranes. Edema formation in livers exposed to thiourea was not completely reversible during the brief $(2 \mathrm{~min})$ perfusion periods of these experiments (the livers remained heavy even when the control runs followed the thiourea experiments). However, significant reversibility of $\left[{ }^{14} \mathrm{C}\right]$ urea transport relative to ${ }^{3} \mathrm{HOH}$ was noted in both the thiourea and phloretin experiments, suggesting that these agents did not permanently impair urea transport.

Since the hepatic sinusoids are discontinuous and the hepatocytes represent the principal cellular constituent of the liver (26), it is likely that the transporter inhibited by thiourea and phloretin is located on the cell membranes of the hepatocytes. This conclusion is supported by the studies of $\left[{ }^{14} \mathrm{C}\right]$ urea unloading in isolated hepatocytes: exposure to phloretin slowed efflux of $\left[{ }^{14} \mathrm{C}\right]$ urea from these cells. However, even in the presence of phloretin, efflux of $\left[{ }^{14} \mathrm{C}\right]$ urea from hepatocytes was observed and the presence of other structures, which are capable of permitting passage of $\left[{ }^{14} \mathrm{C}\right]$ urea but which may not be inhibited by phloretin, is quite possible. For example, Hasegawa et al. have recently reported evidence that $\left[{ }^{14} \mathrm{C}\right]$ urea diffusion may occur through the cystic fibrosis transmembrane conductance regulator (CFTR) (27).

Whereas protein catabolism results in the excretion of $\mathrm{NH}_{3}$ in fish and uric acid in birds, urea is the chief nitrogenous product excreted by mammals. The presence of urea transporters in the cell membranes of hepatocytes may serve to keep urea concentrations within the cells low. Rapid transport of urea out of the hepatocytes could make urea synthesis more efficient by reducing intracellular concentrations of the product. Urea transporters may also minimize cellular swelling which would be expected if significant accumulation of urea occurred within hepatocytes, an event which would raise intracellular osmotic pressure and encourage flow of water into the hepatocytes.

\section{Acknowledgments}

We would like to thank Joan Schultz and Karla Paulson for their invaluable assistance with preparation of this manuscript.

This research was funded by National Institutes of Health grant HL-18606.

\section{References}

1. Dix, J. A., D. A. Ausiello, C. Y. Jung, and A. S. Verkman. 1985. Target analysis studies of red cell water and urea transport. Biochim. Biophys. Acta. 821:243-252. 
2. Mayrand, R. R., and D. G. Levitt. 1983. Urea and ethylene glycol facilitated transport systems in the human red cell membrane. J. Gen. Physiol. 81:221-237.

3. Macey, R. I. 1984. Transport of water and urea in red blood cells. Am. J. Physiol. 246:C195-C203.

4. Chou, C.-L., and M. A. Knepper. 1989. Inhibition of urea transport in inner medullary collecting duct by phloretin and urea analogues. Am. J. Physiol. 257:F359-F365.

5. Zhang, R., and A. S. Verkman. 1990. Urea transport in freshly isolated and cultured cells from rat inner medullary collecting duct. J. Membrane Biol. 117:253-261.

6. Meyer, M. M., and A. S. Verkman. 1986. Human platelet osmotic water and nonelectrolyte transport. Am. J. Physiol. 251:C549-C557.

7. Goresky, C. A., G. G. Bach, and B. E. Nadeau. 1973. On the uptake of materials by the intact liver. J. Clin. Invest. 52:991-1009.

8. Pang, K. S., F. Barker III, A. J. Schwab, and C. A. Goresky. 1990. [14C]urea and ${ }^{58} \mathrm{Co}$-EDTA as reference indicators in hepatic multiple indicator dilution studies. Gastrointest. Am. J. Physiol. 259 (Gastrointest. Liver Physiol. 22):G32-G40.

9. Brigham, K. L., T. R. Harris, R. D. Rowlett, and J. P. Owen. 1977. Comparisons of [ $14 \mathrm{C}]$ urea and [ $3 \mathrm{H}]$ mannitol as lung vascular permeability indicators in awake sheep: Evidence against red cell urea trapping. Micro. Res. 13:97-105.

10. Brigham, K. L., T. R. Harris, and J. P. Owen. 1977. [14C] urea and [14C] sucrose as permeability indicators in histamine pulmonary edema. J. Appl. Physiol. Respirat. Environ. Exercise Physiol. 43:99-101.

11. Ziegler, W. H., and C. A. Goresky. 1971. Transcapillary exchange in the working left ventricle of the dog. Circ. Res. 24:181-207.

12. Rasio, E. A., M. Bendayan, and C. A. Goresky. 1977. Diffusion permeability of an isolated rete mirabile. Circ. Res. 41:791-798.

13. Crone, C. 1970. Capillary permeability-techniques and problems. In Capillary Permeability. C. Crone and C. Lassen, editors. N. A. Munksgaard and Academic Press, Copenhagen and New York. 15-31.

14. Goresky, C. A. 1963. A linear method for determining liver sinusoidal and extravascular volumes. Am. J. Physiol. 204:626-640.

15. Effros, R. M., B. Haider, P. O. Ettinger, S. S. Ahmed, H. A. Oldewurtel, K
Marold, and R. J. Regan. 1975. In vivo myocardial cell pH in the dog: response to ischemia and infusion of alkali. J. Clin. Invest. 55:1100-1110.

16. Seglen, P. O. 1976. Preparation of isolated rat liver cells. In Methods in Cell Biology. D. M. Prescott, editor. Academic Press, New York. 29-83.

17. Knepper, M. A., and R. A. Star. 1990. The vasopressin-regulated urea transporter in renal inner medullary collecting duct. Am. J. Physiol. 28:F393F401.

18. Brahm, J. 1983. Urea permeability of human red cells. J. Gen. Physiol. $82: 1-23$.

19. Macey, R. I., and R. E. L. Farmer. 1970. Inhibition of water and solute permeability in human red cells. Biochim. Biophys. Acta. 211:104-106.

20. Froehlich, O., and R. B. Gunn. 1987. Interactions of inhibitors on anion transporter of human erythrocyte. Am. J. Physiol. 252 (Cell Physiol. 21): C153 C163.

21. LeFevre, P. G., and J. K. Marshall. 1959. The attachment of phloretin and analogues to human erythrocytes in connection with inhibition of sugar transport. J. Biol. Chem. 234:3022-3026.

22. Chou, C.-L., J. M. Sands, H. Nonoguchi, and M. A. Knepper. 1990. Concentration dependence of urea and thiourea transport in rat inner medullary collecting duct. Am. J. Physiol. 258 (Renal Fluid Electrolyte Physiol. 27):F486F494.

23. Imai, M., J. Taniguchi, and K. Yoshitomi. 1988. Osmotic work across inner medullary collecting duct accomplished by differences in reflection coefficients for urea and NaCl. Pfluegers Arch. Eur. J. Physiol. 412:557-567.

24. Goresky, C. A., G. G. Bach, and B. E. Nadeau. 1975. Red cell carriage of label. Its limiting effect on the exchange of materials in the liver. Circ. Res. 36:328-351.

25. Schanker, L. S., and C. A. Hogben. 1961. Biliary excretion of inulin, sucrose, and mannitol: analysis of bile formation. Am. J. Physiol. 200:10871090.

26. Arias, I. M. 1990. The biology of hepatic endothelial cell fenestrae. Problems Liver Dis. 9:11-26.

27. Hasegawa, H., W. Skach, O. Baker, M. C. Calayag, V. Lingappa, and A. S. Verkman. 1992. A multifunctional aqueous channel formed by CFTR. Science (Wash. DC). 258:1477-1479. 